\title{
THE ISOLATION OF COMPOUND POLYPHENOL FROM WAJO DISTRICT CACAO BEAN AND CACAO WASTE THROUGH FERMENTATION PROCESS
}

\author{
Muhammad Wijaya* and Muhammad Wiharto \\ Chemistry Department, Faculty of Mathematics and Natural Science, Makassar State University \\ Jl Daeng Tata-Raya, Makassar, Indonesia, 90224 \\ *email: wijasumi@yahoo.co.id
}

Accepted 26 August 2016 Approved 5 September 2016

\begin{abstract}
This research aims to utilize the liquid smoke, charcoal, oil and gas that have been produced from cocoa waste shell from fast pyrolysis technology at 125-500 ${ }^{\circ} \mathrm{C}$. The charcoal of the cocoa waste was analyzed using a bomb calorimeter at $5925 \mathrm{cal} / \mathrm{g}$ showed that it contains $52.02 \%$ of lignin; $17.27 \%$ of alpha cellulose and $19.56 \%$ of hemicellulose, respectively. The HPLC analysis of Wajo district cacao bean resulted in polyphenol compound as 308.35. GC-MS analysis of cocoa shell liquid smoke that pyrolized at $125-500{ }^{\circ} \mathrm{C}$ produces severals compounds such as acetic acid, n-buthane, methyl esther, propanoac acid, butanoac acid, methyl pyridine, 1-hydroxy-2-propanone, and mequinol. The FTIR analysis of cocoa bean showed a hydroxyl group at $3450.65 \mathrm{~cm}^{-1}$, carbonyl group at $1730.15 \mathrm{~cm}^{-1}, \mathrm{CH}$ group at $719.45-607.58 \mathrm{~cm}^{-1}$. The crystallinity degree of Wajo District cocoa shell analyzed using XRD was 26,50\%. The existence of chemical compounds in liquid smoke products have been found as raw chemicals. Content of biomass carbon at these cacao waste increased according to the increase of pyrolisis temperature, while the carbon emission of these three materials decreased as the temperature increased. Compound polyphenol from cacao bean has a potent as anti oxidant that is friendly for environmental and healthy.
\end{abstract}

Keywords: cacao bean, fermentation, polyphenol, and chemical

\section{Introduction}

The production of chocolate from cacao have been producing biomass waste, such as cocoa shell, cocoa bean, and pod husks [1]. The waste were not utilized properly by thrown away and burned. On the other way, the production of charcoal for urban cooking fuel is a major cause of deforestation, environmental degradation, erosion, desertification and poverty next [2]. Therefore it is a need to find out the content of the cocoa waste and it's potent in order to utilize the waste rather than just throwing away to the environment.

Biomass Pyrolysis is a thermal decomposition process of organic compounds in the absence of oxygen to obtain liquid smoke, charcoal, gas, and sometimes producing oil [3]. Bio-oil is considered as alternatives to petroleum for many solvents, fuels and chemicals and other products [4]. The temperature pyrolysis of waste is usually done in a range between 400 to $800{ }^{\circ} \mathrm{C}$ with parameters heating rate varied from $5{ }^{\circ} \mathrm{C} /$ minute to $25^{\circ} \mathrm{C} / \mathrm{min}$ [5].

The purposes of this study are to determine the content of polyphenols from cocoa beans, produce liquid smoke, charcoal and active carbon through pyrolysis process. Biaoctive chemical compounds that found in the cocoa waste can be recommended to use as chemical raws.

\section{Research Method}

Cacao Pod husks from Wajo District were cut into small pieces with a size of 40-60 Meesh, then dried up to $10-20 \%(\mathrm{w} / \mathrm{w})$. The lignin and cellulose contents were analyzed using Differential Thermal Analyses (DTA/TGA) to determine the decomposition of materials due to temperature changes are made by heating the material to $500{ }^{\circ} \mathrm{C}$ [2]. The pyrolysis process was dane by putting the cocoa pod husks in a kiln made of stainless steel which is equipped with an electric heating device, three capacitors and two pieces of pumpkin container distillate. The combustion temperatures that used were $115-500{ }^{\circ} \mathrm{C}$ in a total time of 5 hours. The resulting liquid smoke formed flowed through each stage is obtained in the bottom of the kiln to the cooler, the condensate is collected in four pumpkin with a volume of 2 liters. The liquid smoke was then collected in the separator flask, 
shaken and left 24 hours of each condensate, to precipitate the pitch. The top of the condensate is a liquid smoke solution, while the bottom is the sediment ter. Liquid smoke pod husks Luwu Regency GC MS analysis is done to determine the chemical compounds that bioacttive. XRD analysis for pod husks and charcoal from cocoa shell.

\section{Result and Discussion}

The TGA/DTA analysis of cocoa pod husks was shown in Figure 1, which showed the lignin decomposition temperature for cacao pod husks from Wajo district is in the range of $507.86{ }^{\circ} \mathrm{C}$, with weight loss at this stage amounted to $30.67 \%$, while for the DTA analysis, it is found in the first peak at $320.12{ }^{\circ} \mathrm{C}$, which started from initial temperature to a final temperature $339.99^{\circ} \mathrm{C}$, generate heat of $16.06 \mathrm{~J}$ and $1.34 \mathrm{~kJ} / \mathrm{g}$. These results are consistent with research reported by Gasparapic et al. [6]. TGA on pyrolysis of wood chips decompose hemicellulose in the temperature range $200-380{ }^{\circ} \mathrm{C}$ and according to Buiyan, et al.
[7] that proved the TGA waste newspapers which the first decomposition was occurred between 38$142{ }^{\circ} \mathrm{C}$. Cellulose decomposition temperature of the skin cocoa fruit is between $325,12{ }^{\circ} \mathrm{C}$ closely related to research that had been done by Gwenzi at al. [8], wherein the cellulose decomposition in the temperature range $250-380^{\circ} \mathrm{C}$. In previous research, thermal decomposition process has been carried out for the pyrolysis of biomass and its constituent mainly contains celluloce, hemicelluloce and lignin types are different [9].

Based on the TGA/DTA analysis results, it indicated that the cocoa fruit skin contains $19.56 \%$ of hemicellulose, $17.27 \%$ of cellulose and $52.02 \%$ of lignin. These result was in agree with Wang et al. [10] that characterized catalyst pyrolized pine wood produced lignin content of $28.6 \%, 30.1 \%$ hemicellulose and cellulose $40.8 \%$, respectively. It is due to that the lignin content highly depend on the different types of raw materials. Lignin does not have a repeat unit as well as hemicellulose and cellulose, but consists of a complex phenolic unit [11].

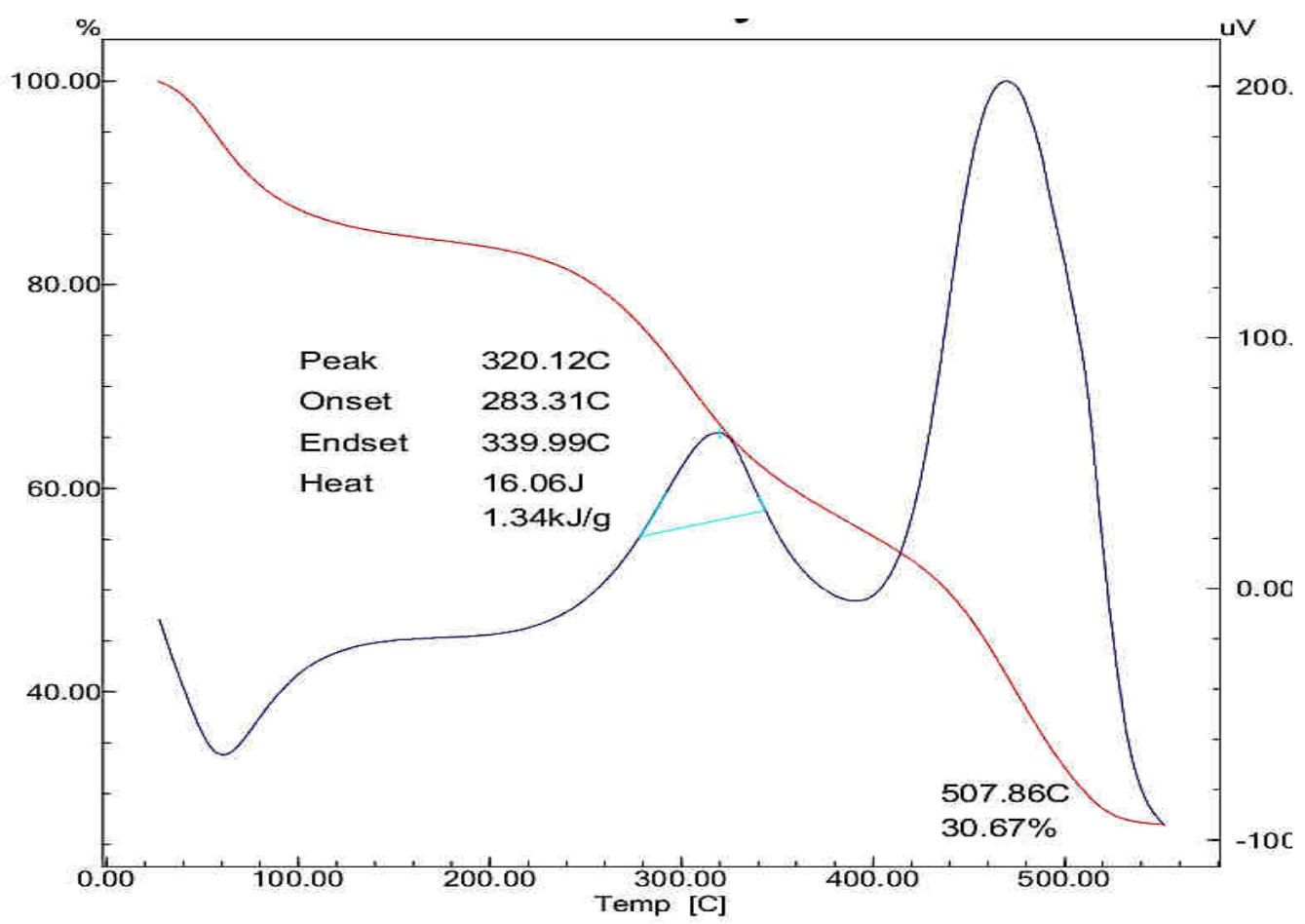

Figure 1. Analysis result DTA / TGA cacao pod husks 


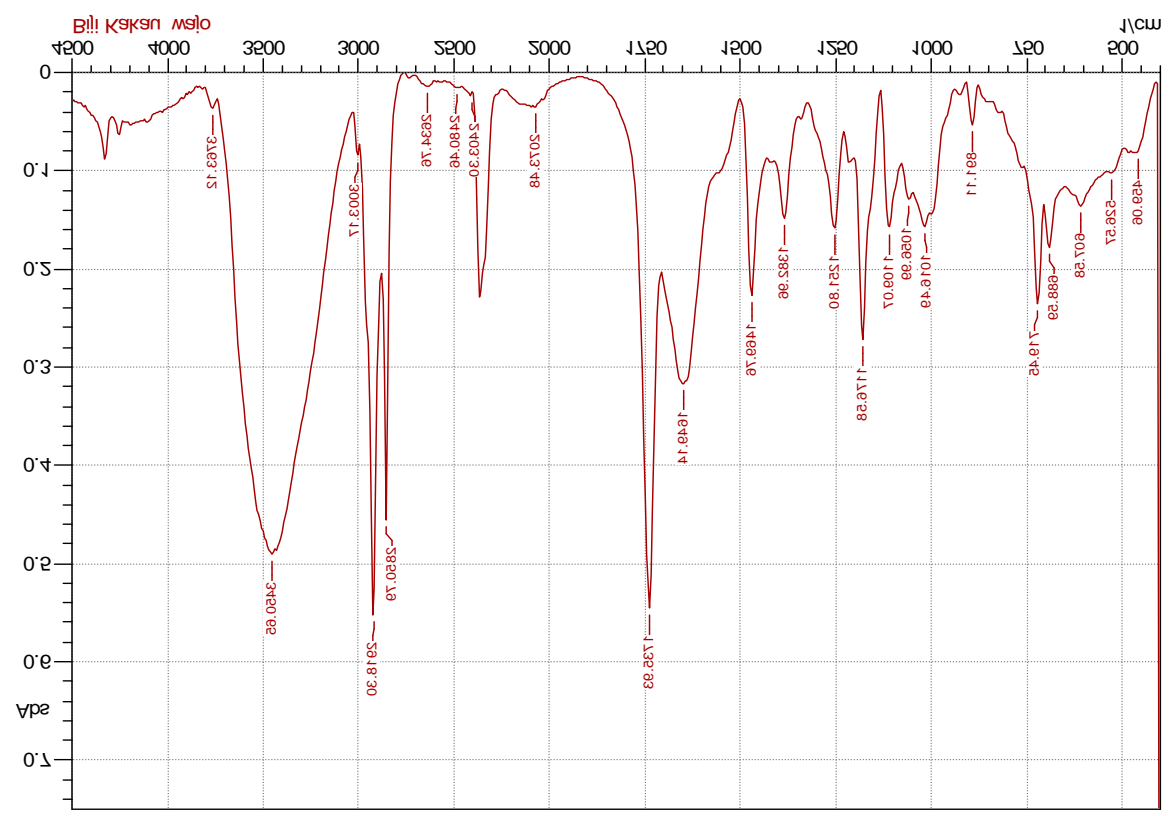

Figure 2. FTIR analysis result of cocoa beans Wajo Distric

FT-IR analysis for cocoa beans of Wajo District (Figure 2) shows that the wave number $1109.07 \mathrm{~cm}^{-1}$ indicated dehydrates and depolymerization groups of cellulose and hemicellulose content. Aromatic peak changes at $1735.93 \mathrm{~cm}^{-1}$ indicates the presence of $\mathrm{C}-\mathrm{H}$ group from lignin. While the wave number $3459.65 \mathrm{~cm}-1$ indicate the presence of hydroxyl group $(\mathrm{O}-\mathrm{H})$ and the absorbance of 719.45 to $607.58 \mathrm{~cm}^{-1}$ indicates the presence of $\mathrm{C}=\mathrm{C}-\mathrm{H}$ (aromatic $\mathrm{H}$ ). The results of this study was suppoerted by the research of Shances et al. [12], which stated that the FTIR analysis for waste fruits showed 3298, 3275 and $3292 \mathrm{~cm}^{-1}$ identified as the vibration $\mathrm{O}-\mathrm{H}$ group of alcohol and pectic acid.

The HPLC analysis relsuted in a highest level of polyphenol compound in cocoa waste of Wajo District as 308.25. That means the contribution of polyphenol compund in cocoa waste, especially cocoa bean is about $12-18 \%$ of the dried weight of the whole bean [8].

Table 1 shows the chemical composition of the cacao vinegar district Wajo obtained from GC MS analysis results are boric acid, n-buthane, methyl ester, acetic acid, propanoic acid, butanoic acid, cyclopentanone, pyridine, 2-methyl-2propanone, 1-(acetyloxy)-, 2-methyl-2-cyclo pentenone, ethanone, 1-(2-furanyl)-, butyrolactone, cyclopenten-1-one, 3-methyl(CAS), 3-methyl-2cyclopentenone, 2-furanmethanol, tetrahydro-, 2-
Cyclopenten-1-one, 2,3-dimethyl-, and mequinol. This suggests that components of liquid smoke on the skin of the cocoa fruit the process of decomposition of hemicellulose and cellulose, it is estimated that many acid formed. Increased acidity caused by heating and organic acid leaching from wood Eucalyptus [9]. Identification of the groups of phenolic compounds, acids, esters, ketones, alcohols, furans and so on, then the separation process is carried out to determine the production of phenolic compounds that have the potential as a chemical base material. The results of this study are supported by [10], that the compounds produced from pyrolysis of corn stalks at a temperature of $450{ }^{\circ} \mathrm{C}$ containing ketones, furan, carboxylic acids and alcohols. Compounds resulting from the pyrolysis of two types of coffee waste (TR1 and TR2) at $300,400,500$, and $600{ }^{\circ} \mathrm{C}$ contains several groups of compounds including phenols, alkanes, alkenes, steroids, acids, esters, ketones, benzene derivatives, and alcohol [1].

XRD analysis for cacao shell Wajo Districtcy of $22.51 \%$ and charcoal cacao shell of $26.50 \%$. The results of other studies indicate that the XRD analysis for the pyrolysis of rice husk mixture (RHS) with the addition of silica carbide ( $\mathrm{SiC}$ ) by $40 \%(\mathrm{w} / \mathrm{w}$ ) after ball milling show that $\alpha-\mathrm{SiC}, \beta-$ $\mathrm{SiC}$, and carbon in the mixing phase. [13] Charcoal yield decreased from $44.72 \%$ to $31.58 \%$ at a temperature of 430-620 C. pyrolysis increased [6]. 
Table. 1. Chemical composition of Cacao Vinegar at various temperatures

\begin{tabular}{|l|c|}
\hline \multicolumn{1}{|c|}{$\begin{array}{c}\text { Chemical composition } \\
\text { of Cacao Vinegar }\end{array}$} & Cooncentration (\%) \\
\hline Boric Acid & 3,64 \\
\hline n--Butane & 13,75 \\
\hline Methyl ester & 1,73 \\
\hline Acetic acid & 61,90 \\
\hline Propanoic acid & 2,31 \\
\hline Butanoic acid & 1,44 \\
\hline Cyclopentanone & 0,99 \\
\hline Pyridine, 2-methyl- & 1,16 \\
\hline 2-Propanone, 1-(acetyloxy)- & 1,09 \\
\hline 2-Methyl-2-cyclopentenone & 1,24 \\
\hline Ethanone, 1-(2-furanyl)- & 0.46 \\
\hline Butyrolactone & 1,98 \\
\hline 3-Methyl-2-cyclopentenone & 1,23 \\
\hline -Furanmethanol, tetrahydro & 2,59 \\
\hline 2-Cyclopenten-1-one, 2,3-dimethyl- & 0,86 \\
\hline Mequinol & 2,63 \\
\hline
\end{tabular}

Table. 2. Proximate analysis cacao charcoal shell District Wajo

\begin{tabular}{|c|l|c|c|c|c|}
\hline No & \multicolumn{1}{|c|}{ Sample } & $\begin{array}{c}\text { Water } \\
(\%)\end{array}$ & $\begin{array}{c}\text { volatile } \\
\text { matter }(\%)\end{array}$ & $\begin{array}{c}\text { ash content } \\
(\%)\end{array}$ & $\begin{array}{c}\text { Fixed } \\
\text { Carbon }(\%)\end{array}$ \\
\hline 1 & Cocoa shell charcoal & 3,235 & 22,555 & 12,239 & 65,206 \\
\hline 2 & Cocoa wood charcoal & 4,849 & 18,671 & 6,243 & 75,086 \\
\hline
\end{tabular}

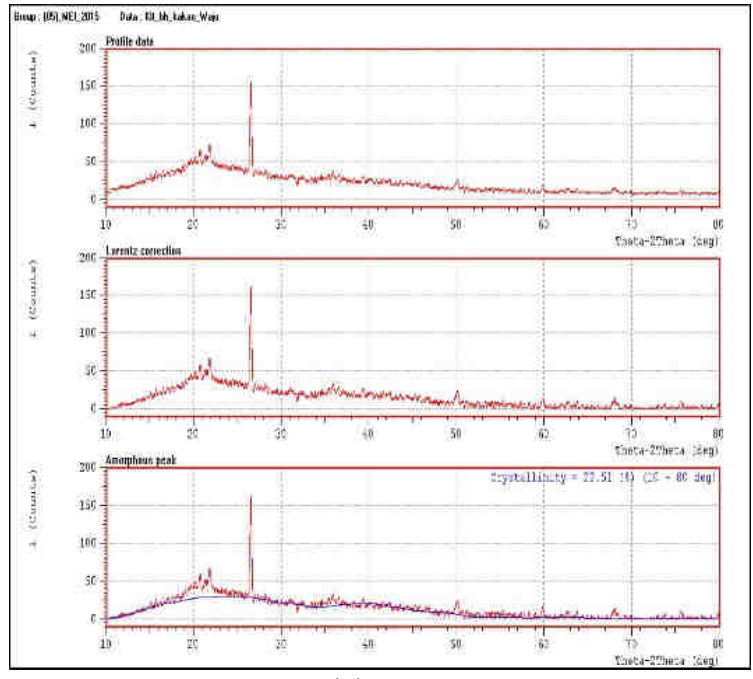

(a)

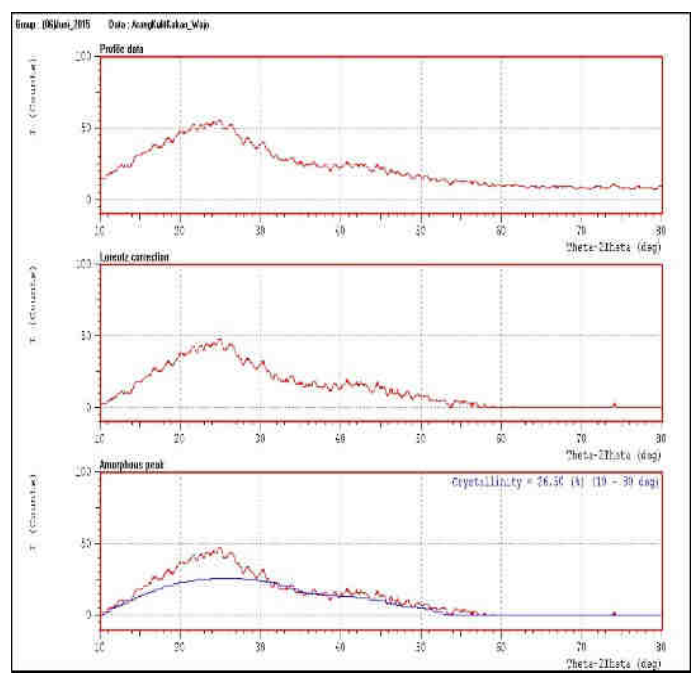

(b)

Figure 3. Result analysis XRD cocoa shell and cocoa shell charcoal

\section{Conclusion}

Based on the objectives and results of research that has been done a number of conclusions as follows: (1). The content of polyphenols from cocoa beans to produce 308.25 Luwu regency, potentially as an antioxidant; (2). Analysis of Luwu Regency rind cocoa pod husks known to produce hemicellulose content of $19.56 \%, 17.27 \%$ cellulose and lignin 52.02\%; and (3). The chemical composition of the liquid smoke pod husks obtained Luwu district of GC MS analysis resulted some raw materials.

Further research is needed for higher temperature variations and the necessary separation 
of compounds for gas products as well as other compounds that have the potential as a chemical.

\section{Acknowledgement}

The authors gratefully acknowledged the Director General of Higher Education Ditlitabmas Kemristek RI on National Competitive Grants and author many expressed thanks and high appreciation to the facilities and infrastructure in research activities to Prof. (R) .Dr.Gustan Pari, MS

\section{References}

[1] Akalin MK, Karagoz S. 2011. Pyrolysis of Tobacco Residue: Part 1. Thermal. J. Biores 6(2): 1520-1531.

[2] Bilmeyer. 1984. Texbook of Polymer Science. New York, John Wiley and Sons.

[3] Bu, Q., Lei, H., Ren, S.J., Wang, L., Holladay, J., Zhang, Q., Tang, J., Ruan, R., 2011. Phenol and phenolics from lignocellulosic biomass by catalytic microwave pyrolysis. Bioresour. Technol. 102, 7004-7007

[4] Bhuiyan MNA, Murakami K, Ota M. 2008. On Thermal Stability and Chemical Kinetic of Water Newspaper by Thermogravimetric and Pyrolysis Analysis. J. Environ. Eng, 3 (1)

[5] Gasparovic L, Korenova Z., Jelemensky L. 2009. Kinetic study of wood chips decomposition by TGA. $36^{\text {th }}$ International Comference of SSCHE

[6] Guo M, and Bi J. 2015. Pyrolysis Characteristics of Corn Stalk with Solid Heat Carrier. J. Bioresources. 10(3), 3839-3851.

[7] Gwenzi, W., Chaukura, N., Mukome, F. N. D., Machado, S., \& Nyamasoka, B. (2014). Biochar production and applications in sub-
Saharan Africa: Opportunities, constraints, risks and uncertainties. Journal of Environmental Management 150C, 250-261.

[8] Hii, CL, Law, CL, Suzannah, S Misnawi, and Cloke, M 2009. polyphenols in cocoa (theobroma cacaoL.) As. J. Food Ag-Ind. 2009, 2(04), 702-722

[9] Kartal SN, Imamura Y, Tsuchiya F, Ohsato K. 2004. Preliminary Evaluation of Fungicidal and Termiticidal Activity of Filtrates from Biomassa Sharry Fuel Production. J Biores Technol $95:$ : 41-47

[10] Lv.G.J, Wu.S.B, and Lou. R. 2010. Characteristic of Corn Stalk Hemicelluloce Pyrolysis in a Tubular Reactor. J.Biores. 5(4), 2051-2062

[11] Noor, NM, Shariff A, Abdullah N. 2012. Slow Pyrolysis of Cassava Wastes for Biochar and Characterization. 2012. Iranica J. Energy \& Environmental 3. 60-65

[12] Shances O, Boldera P, Rou M, Urena P. 2014. Characterization of Lignocelulosic Fruit Waste as Alternative Feedstock for Bioethanol Production.J. Biores 9(2) : 1873-1885

[13] Wang, D, Li D, Dongcan Lv and Liu Y. 2014. Reduction pf the Variety pf Phenolic Compound in Bio Oil via the Catalytic Pyrolysis. J.Biores 8(3), 4014-4021

[14] Yaman, S., 2004. Pyrolysis of biomass to produce fuels and chemical feedstocks. Energy Convers. Manage. 45, 651-671

[15] Zhu D, Gao. M, Pan H, Pan Y, Liu Y, Li S, Ge H, and Fang N. 2014. Fabrication and mehanical Properties of $\mathrm{SiC} / \mathrm{SiC}-\mathrm{Si}$ Composites by Liquid $\mathrm{Si}$ Infiltration using Pyrolysed Rice Husks and SIC Powder as Precursors. 9(2) 2572-2583 